\title{
OPTIMALISASI INTEGRITAS DIRI MELALUI TERAPI KELOMPOK TERAUPETIK LANSIA: STUDI KASUS
}

\author{
Eriyono Budi Wijoyo', Novy H.C. Daulima ${ }^{2}$ \\ ${ }^{I}$ Mahasiswa Spesialis Keperawatan Jiwa, Fakultas Ilmu Keperawatan Universitas Indonesia, eriyonobudi@gmail.com \\ ${ }^{2}$ Dosen Departemen Keperawatan Jiwa, Fakultas Ilmu Keperawatan Universitas Indonesia
}

\section{INFORMASI ARTIKEL:}

\author{
Riwayat Artikel: \\ Tanggal di Publikasi: Desember 2020
}

Kata kunci:

Intigritas diri

Lansia

Terapi kelompok teraupetik

Studi kasus

\section{A B S T R A K}

Latar Belakang: Lansia adalah individu yang berumur diatas 65 tahun dan merupakan proses akhir dalam kehidupan manusia. Perubahan masih dapat terjadi pada usia ini yaitu perubahan psikososial. Menurut teori Erikson dengan perubahan psikososial ini maka dikategorikan pada tahap akhir atau tahap delapan yaitu memasuki tahap integritas diri dan keputusasaan pada lansia. Lansia yang sehat secara fisik dan psikologis dan mempunyai integritas diri maka akan memunculkan perilaku yang adaptif dan normal akan tetapi sebaliknya apabila lansia merasa putus asa maka akan memunculkan perilaku yang menyimpang. Tujuan: Tindakan keperawatan yang bisa dilakukan dengan melakukan adapatasi tersebut adalah dengan melakukan terapi baik individu atau kelompok yaitu terapi kelompok terapetik (TKT) sesuai dengan usia klien. Metode: Proses penulisan artikel ilmiah ini menggunakan pendekatan studi kasus dengan metode deskriptif. Klien dalam kasus ini adalah lansia sehat yang siap untuk adapatasi dengan perubahan yang terjadi pada dirinya. Hasil: TKT lansia berjalan dengan baik dengan 6 sesi dengan 4 kali pertemuan dan dapat dilakukan pada lansia sehat agar sejahtera dan tenang dalam menghadapi hidup ini. 


\section{PENDAHULUAN}

Seorang manusia yang telah memasuki usia diatas 60 tahun biasanya disebut lansia. Hal ini tercantum dalam UU No. 13 tahun 1998 (Kemenkes RI, 2013). Usia lansia mengalami mengalami perubahan biologis, sexual, emosional, sosial dan spiritual. Perubahan tersebut akan berpengaruh pada semua aspek kehidupan lansia termasuk kesehatannya (Fatimah, 2010). Lanjut usia (lansia) didefinisikan menjadi seseorang dengan usia kronologis 65 tahun atau lebih (Shrivastava, Shrivastava, \& Ramasamy, 2013). Populasi lansia di dunia bertambah setiap tahunnya.

Jumlah populasi lansia di dunia akan mengalami peningkatan yang significant di dunia. Jumlah lansia yang berusia $\geq 60$ tahun sejumlah $10 \%$ dan diperkirakan akan terus meningkat pada tahun 2050. Sedangkan untuk lansia yang berusia $\geq 85$ tahun meningkat 0,25 $\%$ dari total jumlah penduduk (Holdworth, 2014). Populasi lansia di Indonesia mencapai angka $7 \%$ pada tahun 2012 dan akan terus meningkat $11,34 \%$ pada tahun 2020. Berdasarkan World Health Organizatition (WHO) di Indonesia pada tahun 2050 akan memasuki peringkat 10 bear dengan populasi lansia sebesar 10 juta jiwa (WHO, 2016).

Perubahan usia harapan hidup atau UHH yang meningkat memberikan konsekuensi dengan meningkatnya jumlah penduduk lanjut usia dibandingkan dengan tahun sebelumnya. Usia yang semakin panjang akan berpengaruh pada penyesuaian tubuh terhadap pemenuhan kebutuhan dasar yang dibutuhkannya. Manusia yang sudah memasuki usia lansia maka akan mengalami penurunan yang bersifat fisiologis berganda (Potter \&Perry, 2005). Perubahan yang terjadi pada lansia mulai dari perubahan biologis terutama fisik dan perubahan psikologis yang meliputi perubahan kognitif, intelektual, aspek sosial serta aspek spiritual serta perubahan seksual (Stuart, 2015; Nugroho, 2008; Aspiani, 2014; Videbeck, 2011; Rahayu, 2016).

Perubahan pada lansia mempengaruhi aktivitas sehari-hari dari lansia itu sendiri. Perubahan ini dapat mengakibatkan gangguan terhadap fungsi fisik dan psikosoal lansia tersebut. Gangguan fungsi yang terjadi dapat mengakibatkan ketergantungan dengan orang lain. Ketergantungan ini dapat dicegah dengan cara mempersiapkan lansia agar dapat mandiri (Guslinda, Keliat \& Widiastuti, 2011). Perubahan fisik maupun biologis yang dialami lansia berupa turgor kulit yang tidak elastis, penurunan indera penglihatan, penurunan indera penghidu, penurunan fungsi pengecapan, pendengaran mulai berkurang serta adanya gangguan muskuloskeletal. Perubahan lain yang muncul adalah pada sistem termoregulasi dan hormonal. Perubahan-perubahan ini terjadi karena proses degeneratif otak (Rahayu, 2016).

Aspek kognitif yang berubah pada lansia yaitu mudah lupa dan penurunan konsentrasi. Perubahan aspek kognitif termasuk dalam perubahan aspek psikologis pada lansia. Pada perubahan psikologis lansia harus memasuki tahap perkembangan yang harus dicapai diantaranya mampu menyesuaikan terhadap proses perubahan kehilangan, kemudian mempertahankan integritas harga diri, dan mempersiapkan kematian (Stuart, 2015). Perubahan sosial pada 
lansia juga menjadi salah satu aspek yang terjadi pada usia lansia.

Perubahan sosial mulai penurunan dikarenakan adanya perubahan fisik dan intelektual pada lansia. Pada dasarnya lansia yang mampu mempertahankan perubahan yang terjadi pada aspek ini dapat dilihat dsecara obyektif bahwa lansia mampu untuk berpartisipasi dalam kegiatan sosial, melakukan interaksi dengan orang lain. Hal ini selain untuk berhubungan dengan orang lain juga dapat menstimulasi fungsi kognitif, sehingga memperlambat proses terjadinya demensia pada lansia (Videbeck, 2011). Proses perubahan sosial yang terjadi pada lansia diantaranya lansia mengalami keterbatasan dalam proses merawat diri (Rahayu, 2016). Perubahan ini dapat menjadikan lansia keterantungan dengan orang lain.

Perubahan pada lansia dan mulai tergantung dengan orang lain membuat aspek emosional pada lansia mengalami gangguan. Hal ini dinilai dari aspek emosional yaitu lansia mudah untuk frustasi, takut kehilangan kemandirian, mudah tersinggung dan merasa kesepian. Perubahan emosional pada lansia merupakan salah satu perubahan yang terjadi secara psikologis (Videbeck, 2011). Perubahan-perubahan ini menjadi penting ketika menghadapi lansia sehingga perlu suatu tindakan keperawatan yang tepat yang bisa mengoptimalkan peran dan fungsi perubahan dan perkembangan psikososial dari lansia.

Perkembangan psikososial pada lansia menurut teori Erikson adalah perkembangan akhir yaitu perkembangan ke delapan. Pada tahap perkembangan ini disebut integritas ego vs keputusasaan (Videbeck, 2011; Parker, 2013). Perilaku lansia dengan tugas perkembangan mempunyai ciriciri normal dan penyimpangan. Lansia yang sehat akan mempunyai perilaku perkembangan yang normal sesuai dengan tahap perkembangannya.

Pada tahap ini perkembangan lansia normal mempunyai perilaku sebagai berikut yaitu memiliki harga diri yang tinggi, dapat menilai kehidupan yang berarti, dapat menerima keuinikan dan nilai dari orang lain, melaksanakan kegaitan agama secara rutin, merasa dicintai. Sedangkan penyimpangan pada perkembangan lansia yaitu melihat rendah atau menghina dan menjelekkan orang lain, tidak memaknai kehidupannya yang berarti, merasakan kehilangan orang yang disayangi serta takut akan waktu luang yang hilang (Ramdani, 2015; Keliat, Helena, \& Farida, 2011). Seorang lanjut usia menjadi sehat apabila dalam kehidupan dapat berfungsi dan berbaur secara efektif dalam kehidupan bermasyarakat.

Lansia sehat merupakan lansia yang aktif dan berfungsi baik secara perkembangan psikososial. Menurut Depkes (2005) seorang lansia dikatakan sehat apabila memiliki kemampuan dan potensi diri serta dapat membantu sesama lansia. Hal ini dapat didukung dengan tindakan keperawatan spesialis yaitu Terapi Kelompok Teraupetik (TKT) (Stuart, 2015). Tindakan TKT tersebut merupakan tindakan yang bisa dilakukan kepada lansia untuk mempersiapkan tahap perkembangan psikososial pada lansia.

Terapi kelompok teraupetik merupakan terapi yang diberikan pada sekelompok orang yang saling bergantung, memiliki norma umum dan saling berhubungan satu dengan yang lain (Townsend, 2003). Hasil dari terapi ini adalah untuk menstabilkan keseimbangan homeostatis yang 
berfokus pada ketidakberfungsian perasaan, pikiran dan perilaku untuk membantu dalam mengatasi penyakit fisik, stress emosi, krisis tumbuh kembang atau penyesuaian sosial (Guslinda, Keliat \& Widiastuti, 2011). Terapi kelompok teraupetik dapat diberikan pada semua tingkat usia sesuai tahap tumbuh kebangnya dan dapat dilakukan secara kelompok dan individu.

Penelitian terkait TKT Lansia terhadap kemampuan adaptasi dan perkembangan integiritas diri lansia pernah diteliti untuk lansia di Padang yang memiliki hasil pengaruh sebesar $61,04 \%$ lansia sehat mengalami peningkatan integritas diri (Guslinda, Keliat \& Widiastuti, 2011). Pada penelitian ini peneliti ingin memaparkan sebuat studi kasus untuk melihat persiapan dan perubahan yang dilakukan pada lansia untuk perkembangan psikososial dengan pelaksanaan terapi kelompok teraupetik lansia. Kasus yang dipaparkan adalah kasus lansia sehat yang dialkukan terapi kelompok terauptik untuk mempersiapkan lansia menjadi sejahtera pada usia lanjut dan memiliki perilaku yang sehat berdasarkan perkembangan psikososial usia lanjut.

\section{METODE PENELITIAN}

Proses penulisan artikel ilmiah ini menggunakan pendekatan studi kasus dengan metode deskriptif. Studi kasus yang dilakukan dengan menilai perkembangan manusia terutama pada lansia dengan pendekatan terapi spesialis keperawatan jiwa. Tindakan keperawatan spesialis yaitu Terapi Kelompok Terapeutik (TKT) Lansia yang terdiri dari 6 sesi yang dilakukan untuk menstimulus perkembangan usia lansia. Penjelasan kasus diuraikan sebagai berikut: seorang lansia perempuan berumur 76 tahun, dengan kondisi fisik sehat dan mengalami perubahan yang normal menjadi seorang lansia. Klien tinggal satu rumah dengan anak laki-laki yang kembar dan sudah 20 tahun ditinggal meninggal pasangannya. Secara subyektif klien mengatakan mudah lelah dibandingkan saat muda dulu. Perubahan biologis yang tampak pada klien mulai dari rambut memutih, mengalami penurunan penglihatan, gigi ompong, kulit kering, kulit keriput dan gerakan terbatas. Perubahan yang terjadi pada klien selain secara biologis tidak ada hal yang mencolok, perubahan kognitif dan emosional pasien sesuai dengan usianya. Klien tidak mudah lupa, tidak mudah penurunan konsentrasi. Serta klien ada perubahan secara spiritual dengan semakin dekat dengan Tuhannya.

\section{DISKUSI}

Klien wanita dengan usia 76 tahun merupakan klien yang memasuki usia lansia yang dikategorikan dalam kelompok lanjut usia tua (old) (World Health Organitation [WHO], 2016). Hal ini berbeda dengan kategori yang dikeluarkan oleh Departemen Kesehatan Republik Indonesia (2013) yang menyatakan bahwa lansia yang berumur 76 tahun memasuki kategori lansia yang memiliki risiko tinggi dapat mengalami penyakit degeneratif.

Kategori dari WHO dan Departemen Kesehatan Republik Indonesia merupakan klasifikasi yang dipakai sampai dengan saat ini. Berdasarkan kasus yang diangkat oleh peneliti bahwa lansia tersebut memang sudah sangat tua dan beresiko dengan penyakit degeneratif. 
Kategori lansia menurut WHO yaitu: a) Usia pertengahan yaitu kisara 45-59 tahun; b) Lanjut usia, antara usia 60-74 tahun; c) Lanjut usia tua antara usia 75-90 tahun; d) Usia sangat tua diatas 90 tahun. Sedangkan pengkategorian menurut Departemen Kesehatan RI (2013) yaitu: a) Virilitas yaitu persiapan usia lanjut yang menampakkan kematangan jiwa (umur 55-59 tahun); b) Usia lanjut dini yaitu kelompok usia lanjut dini (60-64 tahun); c) lansia berisiko tinggi menderita penyakit degenerative (usia > 65 tahun). Perubahan secara biologis pada lansia secara subyektif klien menyampaikan bahwa klien mudah lelah, akan tetapi mampu menahan air kencing sampai dengan toilet dan juga tidak sering berkemih.

Perubahan secara biologis yang disampaikan oleh klien sebenarnya sesuai dengan proses perubahan secara subyektif yang dirasakan oleh klien. Salah satunya mudah lelah membuat kegiatan sehari-hari dari klien terganggu seperti pada saat membersihkan ruangan dan berjalan agak jauh dari rumah ke suatu tempat. Hal ini senada dengan Fatmah (2010) yang menyatakan bahwa proses penuaan dengan menurunnya fungsi tubuh seperti fungsi kardiovaskuler, pernafasan, jaringan dan sistem organ akan mempengaruhi kemunduran kesehatan fisik dan berpengaruh pada activity of daily living.

Perubahan biologis pada klien juga terlihat secara obyektif yaitu adanya rambut rontok, rambut beruban, kulit kering, kulit keriput, gerakan terbatas, gigi ompong dan pendengaran berkurang. Hal ini senada dengan Rahayu (2016) bahwa perubahan fisik yang dialami lansia berupa turgor kulit yang tidak elastis, penurunan indera penglihatan, penurunan indera penghidu, penurunan fungsi pengecapan, pendengaran mulai berkurang serta adanya gangguan muskuloskeletal. Perubahan lain yang muncul adalah pada sistem termoregulasi dan hormonal. Perubahan-perubahan ini terjadi karena proses degeneratif otak. Selain perubahan biologis yang terjadi pada lansia juga terjadi perubahan sexual serta perubahan kognitif.

Perubahan seksual yang terjadi pada lansia secara subyektif yaitu mengalami sakit saat berhubungan dan libido mulai menurun. Hal ini terjadi karena perubahan dalam memproduksi testoteron dan sprema menurun pada usia 45 tahun akan tetapi tidak sampai mencapai titik nol. Memasuki usia 70 tahun seorang laki-laki masih memiliki libodo atau nafsu seksual dan mempu melakukan senggama berbeda pada wanita dengan usia yang sama. Pada wanita dikarenakan jumlah ovum dan volike yang sangat rendah sehingga kadar estrogen juga menurun oasca menaupose usia 45-50 tahun. Kejadian ini menyebabkan dinding rahim menipis, selaput lender mulut rahim dan saluran kencing pada wanita menjadi kering (Tamher \& Noorkasiani, 2009). Sehingga lansia yang berhubungan badan dapat menyebabkan perih. Beberapa hal yang bisa dilakukan selain berhubungan badan pada usia lansia adalah dengan mengelus pasangan, memeluk pasangan dan melakukan latihan kegel untuk melatih otot-otot area kelamin menjadi lebih kuat.

Pada kasus yang diangkat oleh peneliti klien sudah 20 tahun lebih ditinggal meninggal oleh pasangannya sehingga perubahan seksual pada klien terlihat adalah dengan menjaga keharmonisan dengan keluarga. Perubahan fungsi seksual pada lansia berbeda orientasinya yang dulu berasal 
dari penekanan prokeasi berubah menjadi hubungan fisik mencari kesenangan, pertemanan, kedekatan fisik, dan komunikasi intim (Potter \& Perry, 2005). Pada umumnya lansia akan dekat dengan pasangannya kabutuhan seksual pada lansia dapat ditunjukkan dengan berfantasi, berpegangan tangan, berpelukkan dan berhubungan badan (Fatimah, 2010). Seorang lansia dapat melanjutkan untuk berhubungan badan akan tetapi terkadang mereka terbatas karena status kesehatan dan ketiadaan pasangan seperti pada kasus yang diangkat oleh peneliti. Selain perubahan fungsi seksual pada lansia juga akan mengalami perubahan sosial.

Perubahan sosial pada klien mulai penurunan hubungan dengan lansia lain dikarenakan perubahan fisik yang terjadi pada klien. Menurut Videbeck (2011) menyatakan bahwa lansia mampu untuk berpartisipasi dalam kegiatan sosial, melakukan interaksi, menstimulasi fungsi kognitif, sehingga memperlambat proses terjadinya demensia. Hal ini juga dilakukan oleh klien dengan mendatangi teman atau keluarganya dalam lingkungan yang sama. Hal ini menurut klien untuk proses sosisalisasi dan juga mendengarkan kabar keluarga atau teman serta tetangga yang di datangi. Kegiatan ini ternyata juga mendukung untuk proses pencegahan dimensia pada lansia. Selain itu menurut klien hal ini dilakukan juga untuk menghindari rasa bosan atau kesepian yang melanda pikiran klien. Seperti pernyataan teori Erikson yang menyatakan bahwa pada perubahan perilaku maladaptive salah satunya dengan adanya perubahan psikologis salah satunya adalah perubahan kognitif dan pada aspek emosional lansia merasa kesepian (Ramdani, 2015; Keliat, Helena, \&
Farida, 2011). Hal ini juga sesuai dengan kasus bahwa klien kadang merasa sendirian dan takut akan muncul piiran atau kehilangan kemandiriannya.

Perubahan sosial ini mengajarkan lansia untuk berinteraksi dengan orang lain baik seumuran atau lebih muda. Selain itu dapat mengurangi untuk proses perawatan diri klien sendiri. Perubahan sosial yang terjadi pada lansia diantaranya lansia mengalami keterbatasan dalam proses merawat diri (Rahayu, 2016). Akan tetapi pada kasus yang diangkat tidak terjadi perubahan sosial yang berarti hal ini diindikasikan klien memiliki sahabat, tidak merasa kesepian karena ada tetangga dan keluarga yang memperhatikannya.

Perubahan sosial secara obyektif terlihat bahwa klien bergaul dengan orang lain dan aktif dalam kegiatan sosial seperti mengikuti hajatan di tetangganya dan proses bersih-bersih di lingkungan tempat tinggal. Hal ini juga merupakan perilaku yang adaptif pada lansia yang mengalami perubahan psikososial sesuai dengan tahap perkembangan lansia. Perubahan normal ini merupakan dari proses integritas diri lansia dengan berpartisipasi dalam kegiatan sosial dan kelompok masyarakat. Hal ini senada dengan karakteristik yang disampaikan Ramdani (2015) yang menyatakan tahap perubahan sosial lansia yang normal adalah integritas diri dengan perilaku lansia seperti yang ditunjukkan oleh klien di atas.

Perubahan sosial yang ditunjukkan oleh klien termasuk dalam perubahan yang adaptif dan sesuai dengan perkembangan lansia yang normal. Selain perubahan sosial pada lansia, perubahan yang tidak kalah penting yaitu perubahan aspek spiritual. Aspek ini menilai hubungan antara klien 
dengan Tuhannya dan juga intensitas yang sering terkait dengan doa, ritual keagamaan dan juga kegiatan religi lainnya.

Perubahan spiritual dalam diri klien ditunjukkan dengan adanya klien yang mengikuti kegiatan pengajian tiap pekan dan juga beribadah harian. Klien memeluk agama Islam sehingga dalam pelaksanaannya proses kegiatan beragama klien dilakukan dengan sholat 5 waktu berjamaah di mushola dan juga berdoa selalu agar dimudahkan untuk segala urusannya yang dihadapainya. Selain itu klien juga menggunakan pakaian yang menutup aurat dari badannya. Hal ini terlihat klien berjilbab dengan menggunakan pakaian panjang untuk menutup auratnya.

Aspek perubahan spiritual ini mengkaitkan agama dengan kehidupannya dan ada integrasis didalamnya (Guslinda, 2011). Ini juga sesuai dengan pemikiran klien bahwa agama dengan kehidupan tidak bisa dipisahkan karena merupakan satu kesatuan. Semakin tambah usia maka semakin bertambah pula kadar keimanan seseorang dengan mempertebal kegiatan keagamaan dan juga kegiatan religi lainnya. Hal ini senada dengan Zakiyah \& Hasan (2015) yang menyatakan lansia mengalami penurunan sceara fisik akan tetapi kegiatan yang berhubungan dengan spiritual mengalami peningkatan. Kegiatan spiritual seperti peningkatan kedekatan lansia dengan Tuhannya dengan kegiatan agamnya. Klien menyadari bahwa semakin tua akan semakin buta dunia maka akan diperkuat dengan agama.

Perkuatan agama dalam hal ini bertujuan untuk menyelesaikan berbagai maslaah kehidupan dan sebagai pegangan hidup selama di dunia ini. Penyataan tersbut sesuai dengan yang disampaikan oleh klien bahwa semakin tua akan semakin buta maka perlu dibimbing yaitu dengan ilmu agama. Stuart (2009) juga menyatakan kegiatan agama dalam melaksanakan ibadahnya menjadi sarana yang baik dalam penyembuhan penyakit neurosis yang diderita pada orang yang berusia 45 tahun keatas yang berhubungan dengan kematian, pemaknaan kehidupan dan arti dari kehidupan ini sendiri.

Perubahan aspek spiritualitas adalah perubahan terakhir yang dialami oleh lansia. Berbagai perubahan perkembangan yang ada pada lansia yaitu perubahan perkembangan biologis, seksual, kognitif, emosional dan spiritual merupakan aspek perubahan yang pasti terjadi pada lansia. Maka dari itu perlu penilaian dan juga perlu adanya pemantauan agar lansia siap menghadapi perubahan tersebut. Tindakan keperawatan yang bisa dilakukan untuk menyiapkan lansia menghadapi dan dapat beradapatasi dengan perubahan tersebut adalah dengan melakukan TKT Lansia.

TKT Lansia merupakan terapi yang dilaksanakan pada kelompok dengan usia yang sama yaitu usia lansia sehingga biasa disebut TKT lansia. TKT ini dilakukan pada kelompok dngan usia yang sama, pada klien yang diangkat pada penelitian ini kasusnya adalah seorang klien yang berusia lansia yang sudah dilakukan TKT lansia dengan menilai 5 aspek perubahan mulai dari biologis, seksual, kognitif, emosional, sosial dan spiritual dan melakukan onitoring dan evaluasi yang dilakukan untuk masing-masing aspek perubahan yang dinilai.

Penilaian aspek perubahan dalam TKT Lansia ini dibagi menjadi 6 tahapan atau sesi dan setiap tahapan dilaksanakan dalam waktu 30-45 menit. 
Pelaksanaan TKT Lansia ini dibagi menjadi 4 pertemuan dengan menyatukan sesi 1 yaitu stimulasi adaptasi perubahan aspek biologis dan seksual dan sesi 2 yaitu melakukan stimulasi adaptasi perubahan aspek kognitif yang dilakukan maksimal 1 jam atau 60 menit. Lalu untuk pertemuan kedua dilakukan pekan selanjutnya yaitu dengan menyatukan sesi 3 yaitu melakukan stimulasi adaptasi perubahan aspek emosional dan sesi 4 melakukan adaptasi perubahan aspek sosial sedangkan pada pertemuan 3 dilakukan sesi 4 (Stimulasi adaptasi perubahan aspek spiritual) dan pertemuan terakhir yaitu melakukan monitoring dan juga evaluasi pengalaman dan manfaat latihan (FIK UI, 2016).

Pada pelaksanaan sesi 4 terkait stimulasi adaptasi perubahan aspek spiritual dialkukan pertemuan sendiri karena aspek ini mrupakan aspek yang mendalam yang dikaitkan dengan penerimaan sebagai lansia dan penerimaan makna serta arti kehidupan. Jadi perlu waktu dan tempat yang lumayan lama untuk sesi ini. Pelaksanaan pada TKT lansia ini menilai perubahan yang terjadi pada lansia dan juga melakukan latihan serta mengevaluasi tindakan yang dilakukan sebagai pekerjaan rumah sebelumnya.

Penilaian kegiatan sebelumnya berjalan dengan baik dan klien menunjukkan adanya perubahan dan melakukan penjadwalan pada aspek perkembangan yang berubah pada diri klien. Aspek perkembangan yang berubah pada klien yaitu adanya pernyataan secara subyektif bahwa ada perubahan secara emosional yang mulai terkontrol dan juga adanya perubahan dalam memaknai kehidupan yang dilalui sampai dengan saat ini. Pelaksanaan TKT Lansia berjalan dengan baik dan dapat dilakukan pada lansia yang sehat baik secara individu atau kelompok. TKT lansia ini juga bisa dilakukan dengan menilai adaptasi yang ada pada lansia. Penelitian ini sesuai dengan penelitian Guslinda, Keliat dan Widiastuti (2011) dengan hasil TKT lansia dapat meningkatkan integritas diri pada lansia yang sehat.

\section{KESIMPULAN DAN SARAN}

Aspek perkembangan yang berubah pada lansia dapat menyebabkan hal yang tidak diinginkan. Hal ini menjadi tidak baik ketika lansia tersebut tidak dapat beradaptasi dengan baik akan tetapi menjadi baik ketika lansia dapat beradaptasi dengan baik. Aspek perkembangan lansia yang berubah mulai dari aspek biologis, seksual, kognitif, sosial, spitual sehingga perlu adanya terapi untuk menjadikan lansia dapat beradapatasi dengan perubahan tersebut. Perubahan yang terjadi pada lansia dapat dikawal dengan terapi baik individu atau kelompok yaitu kegiatan terapi kelompok teraupetik (TKT) khsusunya untuk usia lansia yaitu TKT Lansia agar dapat mengoptimalkan fungsi dan bisa beradapatasi dengan perubahan yang terjadi pada lansia sehat. Keterlibatan dari stakeholder dan kader kesehatan serta Puskemas setempat memjadi hal yang penting untuk mengontrol dan mendampingi terapi ini. TKT Lansia dapat dikombinasikan dengan kegiatan Posbindu untuk lansia dengan pengurus kader kesehatan untuk memaksimalkan kegiatan ini.

\section{DAFTAR PUSTAKA}

Depkes RI. (2005). Pedoman Pembinaan Kesehatan Lansia Bagi Petugas Kesehatan I. Jakarta. 
Fakultas Keperawatan Kekhususan Keperawatan Jiwa. Universitas Indonesia.(2016). Draft Scanning dan Standart Asuhan Keperawatan. (tidak dipublikasikan).

Fatimah. (2010). Merawat Manusia Lanjut Usia Suatu Pendekatan Proses Keperawatan Gerontik. Jakarta:CV.Trans Info Media.

Guslinda, Keliat \& Widyastuti (2011). Pengaruh terapu kelompok Terapeutik Lansia Terhadap Kemampuan Adaptasi dan Perkembangan Integritas Diri Lansia di Kelurahan Surau Gadang Kecamatan Nanggalo Padang. Diakses melalui http://lib.ui.ac.id

Holdsworth, G. J. W. A. M. M. (2014). Gizi dan Dietetika ( a Handbook of Nutrition and Dietetics) (2nd ed). Jakarta : Penerbit Buku Kedokteran EGC.

Keliat, B. A., Helena, N., \& Farida, P. (2011). Manajemen keperawatan psikososial dan kader kesehatan jiwa: CMHN (ntermediate course). Jakarta: EGC.

Keliat, Anna Budi, Akemat, Novy Helena. 2007. Keperawatan Kesehatan Jiwa Komunitas: CMHN (Basic Care). Jakarta: EGC.

Kementrian Kesehatan RI. (2013). Gambaran Kesehatan Lanjut Usia di Indonesia. Jakarta: Pusat Data dan Informasi Kementrian Kesehatan RI.

Nugroho, W. (2008). Keperawatan Gerontik dan Geriatrik, Edisi 3. Jakarta: EGC.
Parker, D. W. (2013). The Relationship Between Ego Integrity and Death Attitudes in Older Adults. American Journal of Applied Psychology, 2(1), 7. https://doi.org/10.11648/j.ajap.2 0130201.12.

Potter, P.A, Perry, A.G. 2005. Buku Ajar Fundamental Keperawatan : Konsep, Proses, dan Praktik.Edisi 4.Volume 2. Jakarta:EGC.

Rahayu, S. (2016). Pengalaman Lansia Tinggal di Panti Sosial Tresna Werdha (PSTW) dalam Menjalani Kehidupan Masa Tua Studi Fenomenologi. Tesis. Depok: Program Magister Ilmu Keperawatan Fakultas Ilmu Keperawatan Universitas Indonesia.

Ramdani. (2015). Kontribusi Kecerdasan Spiritual dan Dukungan Keluarga Terhadap Kepuasan Hidup Lansia Serta Implikasinya Dalam Pelayanan Bimbingan dan Konseling. Jurnal Kopasta, 2(Tidak dipublikasikan), 111-115.

Shrivastava, S. R., Shrivastava, P. S., \& Ramasamy, J. (2013). Healthcare of elderly: determinants, needs and services. Int J Prev Med, Oct; 4(10): 1224-1225.

Stuart, G. W. (2015). Principles and practice of psychiatric nursing 10th edition. Riverport Lane, St Louis, Missouri: Mosby Elsevier.

Tamher, S. \& Noorkasiani. (2009). Kesehatan Usia Lanjut dengan Pendekatan Asuhan Keperawatan. Jakarta: Salemba Medika. 
Townsend, M. C. (2013). Essentials Of Psychiatricc Mental Health Nursing. (3rd ed) Philadelphia : F. A. Davis Company.

Videbeck, S. L. (2011). PsychiatricMental Health Nursing. Philadelphia: Lippincott Williams \& Wilkins.

WHO. 2016. Dementia. Diunduh dari http://www.who.int/mediacentre /factsheets/fs362/en/

Zakiyah, Z \& Ibnu Hasan. 2015. Studi Religiusitas LAnsia Terhadap Perilaku Keagamaan pada Lansia Perumahan Tegal Sari Ledug Kembaran, Banyumas. Islamadina. Vol.XV, No. 2. 